\title{
Epiphany
}

Epiphany: Vol. 6, No. 2, 2013

ISSN 1840-3719

\section{Poetic Experience}

Shahab Yar Khan*

\begin{abstract}
Nature of poetic experience is hereby redefined. The present article initially deals with the perennial nature of true poetic experience and its essential relevance to the world. It attempts to elaborate the process through which a poet is uplifted in a creative moment beyond terrestrial boundaries and is aligned with the 'state of Perfection'. The role of successive generations of audiences in rediscovering the meaning of a poetic image is defined as life principle of all great poetry. Shakespeare is discussed as the ultimate example of this principle since his popularity remains an irreversible phenomenon.
\end{abstract}

Keywords: Poetic Experience; Mysticism; Beatific Vision; Symbolism; Naturalism and Shakespeare. 
Poetic experience involves a nexus of esoteric and exoteric happenings. Total recognition of these happenings makes a true poet to surrender voluntarily his conscious being to those senses that are particular modes of non-duality; this eventually leads him to a 'discovery'. This experience is that unique moment of awareness in which poet discovers and rediscovers a perennial existence of cosmic nature ---- the state of 'absolute perfection'. Thoughts, then, uninterrupted by a terrestrial barrier flow, to and fro, from the center of poet's being to the center of the cosmic being. This 'Perfection'-poet alliance, as the result of the poetic impulse, forces the later to feel, understand and trace out all the possible dimensions of the first. This establishes an objective correlative between the two. The poet identifies his own self as one with the existence. If this progression from periphery to center, from finite to infinite, from form to meaning continues the poet would enter the realm of 'beatific vision', the promised land of the mystics and Sufis who remain to this day the selfless, contemplative element of any society. Poet's impulse to recreate, as compared to a Sufi's selfless surrender to and timeless glaring at this vision, forces him to withdraw from this loftiest state of human mind and soul. He decides not to break through the terrestrial crust, deprives himself of all the possibilities of becoming one with the beatific vision and returns to begin sharing his experience with his audience. As a matter of fact, all great poetry is a scrambled record of the experience of this moment. That's what Longynus, the wisest of the Thebans, and in our days Joan Elya (renowned Pakistani Urdu poet of late $20^{\text {th }}$ centutry) meant when they suggested 'sole purpose of composing poetry should be the transference of experience (Kefiyat in Urdu/Arabic, Ekstasis in Greek) from the poet to the audience' (Eliya, 1996, p. 14).

Audience, at this stage, becomes formulating factor for the 'mode of inspiration', distinguishable thoroughly from the 'mode of thinking-withpurpose'. This mode of inspiration is never a result of a plan; it results into a plan. This unintended plan is actually a symbolic set of values of diverse nature, at times vague but always impressive and suggestive. In this way every great poet goes beyond the boundaries he originally sets 
for himself. Audience is the reciprocal agent to these sets of values. Successive generations of this 'reciprocal agent' give versatile meaning to these values and in the process detach the original poetic experience from its end product. The meaning of the true poetic experience, thus, becomes subject to further deciphering of the poetic hieroglyph ----- the poetic image. De-codification of poetic image is the life principle of poetry. Lewis (1965) believes that not only image is the constant in all poetry; every poem itself is an image. Discussing the nature of poetic imagination he says:

'When we speak of imagination, then we speak on the one hand of a sympathy common to all men, though in the poet specialized, cultivated and intensified, and on the other hand, a perpetual reaching out of this sympathy towards objects otherwise unattainable --- towards the past, the future, the absent, all that lies beyond the compass of present experience, without which the meaning of this experience must be so much the less distinct and complete. The nature of poetic sympathy is revealed in images, and I do not know any better way of defining it than by selection of images in which poets have embodied this sympathy, or attested to it. We remember Shakespeare's lines:

Love's feeling is more sensible

Than are the tender horns of cockled snails.

Then there is Keats:

The setting sun will always set me to rights --- or if a sparrow comes before my window I take part in its existence and pick about the Gravel. And Blake:

Arise your little glancing wings and sing your infant joy! Arise and drink your bliss, for everything that lives is holy. And Mr. MacNeice speaking of his days in Birmingham:

The short square fingers stuffing pipes were not poetic romantic objects abstracted in a picture of Picasso, but were living fingers attached to concrete people --- were in a sense my fingers.

We look as such images as those, and we live in them, that sustaining love

Which through the web of being blindly wove

By men and beast and earth and air and sea 
Burns bright or dim, as each are mirrors of

The fire for which all thirst'. (Shelley)' (p. 66).

This kind of study of a certain text makes Shakespeare's writings unprecedented in inspiring successive generations of mankind. Over the centuries, the textual and inter-textual history of his plays has been written down time and time again. Not only the otherwise fossilized Elizabethan world finds a life giving force in Shakespearean drama but also the literary criticism in general, considered as 'barren landscape' by ordinary readers, receives fresh air from his art. He as a cliché is 'for all ages' but his popularity as an ever-growing, irreversible phenomenon has never been the fate of someone merely human, up to this day this is ultrahuman. He, the author of the 'secular Bible' knew well his destiny when he claimed with authority:

“... how many ages hence this lofty scene of ours

Would be acted in lands not yet seen

And in accents not yet known (cited in Bloom, 2003, p. 3).

"He is ranked with the very few, Beethoven, Mozart, Leonardo de Vinci, Michelangelo, Picasso, Tolstoy - one of the greatest artists of Western civilization" (p. 1). Thus says Scott (1993), very modestly. The fact is that Shakespeare's is a caliber that raises him above such labeling as Westerner or English only; he is definitely one of the greatest if not the greatest artist of human civilization. If Shakespeare were only a Westerner or English, the greatest opponents of the British Empire and the Western culture in India, Muhammad Iqbal and Robindtranath Tagore would not have paid their tributes to him. Iqbal, the great poetphilosopher and the spiritual father of Pakistan, paid tribute to the great genius in the following words:

\section{Shakespeare}

"To the rusty morn, flow of the river is the mirror; to the evening song, evening's silence is the mirror. Beauty is the mirror of Truth and heart is the mirror of Beauty, to mankind's heart the beauty of your words is the mirror. Your thoughts ascending to heavens are the apex of existence while meaning of existence is your illuminated being. When the eye, desirous of the Vision, searched for you, in the glow of the sun, it did see 
the sun inherent. From the eyes of the world your truth remained concealed but the world revealed, your eyes did see. Secrecy, a concern of Nature, is of such kind that a confidant of your kind will not be born again."

(Translated from Urdu collection of poems, Bang-e-Dara).

National poet of India, the great religious and social reformer and the first Asian ever to win Noble Prize for literature, Rabindranath Tagore wrote the following poem on Shakespeare's three-hundredth death anniversary: "O universal poet!

Whose sun rose on the distant shore.

England found you in her breast,

Thought you were her own.

Kept you,

Kissing your shining brow,

In forest boughs a while embraced,

Where fairies danced and flowers bloomed.

The island groves resound

With praise, sung for this rising sun.

Then the sun leaped from its horizon's lap,

Wordlessly called from the infinity,

Climbed up the centuries hour by hour

To reach the zenith of his glory,

Enlightening the mind of the world.

See now from the far off shores of India,

From her coconut groves,

At this end of the time

Jingles his song of victory" (www.msci.memphis.edu).

Shakespeare is universal because of a mystical quest which results always as Lewis says, from "congruity of images." The seeds of his imagery, a perennial quest, lie in the very nature of the things. His poetry is life itself. I will not hold the position that his poetry is criticism of life, which according to Matthew Arnold, is the very definition of poetry. Neither will I go for the proposition that life itself is the criticism of his 
poetry, which according to Iqbal (1992), is the 'truth of all great poetry' (p. 34). It is important, though, to mention that the word poetry in both the cases is used in its widest possible sense. It includes all kinds of poetic expressions with which the eastern or the western traditions of arts are familiar. It also includes all kinds of poetic drama whether ancient Indo-Greek, Elizabethan or modern. All such art forms are means through which an artist appeals the unconscious part of us. As E. S. Dallas, a Victorian poet once said:

"The production of imagery belongs to the general action of the mind, in the dusk of unconsciousness." An image may in fact be another name for the concentration of the 'greatest possible amount of significance into a small space'. This intense feeling, transferred to the audience either through separate image or through the close patterns within which a poem's images are related, is even stronger in poetic drama. "In poetic drama, the imagery need not be so carefully selected or closely fused as in the lyric; mixed metaphors, for instance, are more readily acceptable in so far as the dramatic argument it self has enough impetus to jump the gap between them" (Lewis, 1965, p. 89).

What Lewis here is talking about is the discovery of Caroline Spurgeon's 'theme image' in a play. This important discovery that through a number of variations this image keeps on repeating itself has helped critics to examine the process by which a playwright, particularly an Elizabethan playwright, deploys his imagery. The Elizabethan deployment of imagery is directly connected with what is called by Greenblatt (1984), 'fashioning of human identity as a manipulable, artful process' (p. 2). Shakespearean drama, as a result, is a 'ceaseless narrative invention'; it's in fact an attempt to see oneself in the other fellow's situation.' Greenblatt sees Shakespearean drama as the supreme purveyor of empathy, the fashioner of narrative selves. Montaigne (1958), who shares many of Shakespeare's most radical perceptions is another good example of non-narrative self-fashioning, 'I cannot keep my subject still. It goes along befuddled and staggering, with a natural drunkenness. I take it in 
this condition, just as it is at the moment I give my attention to it' ( $\mathrm{p}$. 122).

Such flexibility transformed the symbolic structure of Elizabethan art. Shakespeare used this method to create a kind of drama which is of 'no genre' and that would in future transcend all geo-cultural and even religious barriers. But the question (is his drama criticism of life or life as its criticism qualifies it?) remains unanswered if we do not analyze the two apparently identical statements by Arnold and Iqbal. In fact the two statements are two different perspectives of the two thinkers who mirror the differing destinies of the East and the West. In Arnold's statement the word life actually means 'Nature', as a site of rational analysis and dissection. Poet's job is to understand the complexity of this phenomenon and to reinterpret it in such pleasurable way that it would become a fragment of human knowledge. In Iqbal's statement, however, the word 'life' stands for that harmony between reason and spiritual perceptions that affect the 'imaginal world' of a poet. It is because of this oriental attitude that in the East intellectuals "were rarely able to conceive of nature without seeing its roots in God, it cannot be studied without an investigation of the moral and ethical demands that this rooting entails" (Chittick, 2001, p. 16).

On the other hand, in the West after the Dark Ages the scholars were looking upon 'unrooted knowledge' as an object worthy of pursuit (Armstrong, 2000, p. 15). As a result of this pursuit a complex process was at work in Europe by the time Shakespeare appeared on the scene of English stage. In an era when the most influential writer of the world, William Shakespeare, was about to bring the continents closer than ever; the world was heading forward towards a split it had never seen before. This unprecedented split, in the last two decades, has attracted the attention of scholars all over the world and enormous amount of work, expounding the nature of Eastern mythos and Western logos, rationalism and Sufism, has been carried out by illustrious figures such as Frinthjof Schoun, Titus Burckhardt, Henry Corbin, Martin Lings, S. H. Nasr, William Chittick, etc. All such scholars have a very keen eye on the inner 
relation of spiritualism with the Eastern art and the lack of 'metaphysics and theology of nature' in the West:

"Since Giordano Bruno has broken the boundaries of the cosmos and hence destroyed the very notion of the cosmos, which means literally 'order' the universe has become limitless outwardly. But precisely due to a lack of metaphysics or theology of nature in the West, the symbolic meaning of this new vision of the universe has not been made generally known, and moreover, because modern science leaves aside the symbolic significance of things, the content of this outwardly infinite universe remains finite. It is bound to the purely material level of existence. In a sense the situation has become reverse of what existed in traditional sciences (Eastern tradition). There the cosmos is outwardly finite but with an inner content that leads to the Infinite, whereas in the modern science the universe is outwardly infinite but inwardly finite. Hence, on the one hand modern man seeks to conquer the space, due to an unconscious urge or 'mystique' to transcend his earthly finitude --- but in a physical manner which is the only manner modern man believes to be possible --and on the other hand those modern men who realize the implication of the finiteness of the contents of the universe is subdued by this very realization and seeks an outlet from the tyranny of the physical world through the use of drugs, which they believe will open to them 'the doors of perception' into another world" (Nasr, 1999, p. 19).

This perception of difference elaborates the way in which the two worlds of the East and the West primarily depend on their 'mythos' or 'logos'. This difference, a couple of centuries ago an intellectual stimulus, is now the cause of a mental and moral inertia. As a result, the followers of either belief have become endangered species. Today it is a global killer. In 1993, Journal of the American Academy of Religion published the following statement in an article by J. A. Burling, "We live and work in cultures that are wrestling with a complex web of issues related to religious pluralism and cultural diversity". There is no doubt that more than ever now is the need for the revival of sophistication to understand the differences in a world where diversity of opinion is no more a blessing but once again such a heresy, which deserves inquisition. 
Shakespeare, 'the cosmic soul', knew that diversity is the essential law for existence and primary principal of all creation. Today, he stands as a ray of hope amidst the forces of chaos around us. He is among those who have, consciously or unconsciously attempted to bridge the gulf between the diverse conflicting natures of mankind. In Shakespeare, drama rises above the classical clash between the forces of the good and the evil. 'Diversity' becomes the soul of drama instead of 'Conflict'. This 'problem of diversity', four centuries before Shakespeare was discussed first by Ibn Arabi (b.1165), who, like Shakespeare, believed that diversity (Masala-ikhilaf) is that principal which is established by God's wisdom and compassion.

Shakespeare with the help of his characters creates a world of matrix where unlimited dimensions of 'being' force the reader to see the possibilities within and lead to experience an existence which raises one above the physical barriers of time, space or cast and creed. Shakespeare, a universal man, is the only common phenomenon in man's diverse cultures today. His insight into the nature of the existence enabled him to win admirers, followers and critics from all the present day cultures specially those which experienced directly the most far reaching phenomenon in human history, the British Empire. Once more a cliché, 'he is of no age', in fact, he is an age himself and unto this day the world has not seen an era which could be called 'post Shakespearean era'.

\section{References}

Lewis C. D. 1965. Poetic Image. London: Cox and Wyman Ltd.

Bloom Harold. 2003. The Poem Unlimited. New York: River Head Books.

Iqbal Javed. 1992. Stray Reflections. Lahore: Iqbal Academy.

Eliya John. 1996. Shayed. Lahore: Alhamd Publications.

Armstrong Karen. 2000. The Battle for God. London: Harper Collins Publishers.

Scott Michael. 1993. Shakespeare and Modern Dramatist. Basingstoke: The Macmillan Press Ltd. 
Of Repentance. 1958. Complete essays of Montaigne. Stanford University Press.

Nasr S. H. 1999. Living Sufism. Lahore: Sohail Academy.

Greenblatt Stephen. Renaissance Self-Fashioning. Chicago: University of Chicago Press.

Chittick William. 2001. Imaginal World. Lahore: Sohail Academy. 